\title{
PENGARUH MODEL PEMBELAJARAN DISCOVERY LEARNING TERHADAP HASIL BELAJAR SISWA
}

\author{
Yesi Puspitasari, Siti Nurhayati \\ STKIP PGRI Situbondo \\ yesipuspitasari@stkippgri-situbondo
}

\begin{abstract}
Abstrak Model Pembelajaran Discovery Learning merupakan model pembelajaran dimana peserta didik memahami sendiri konsep, arti, dan hubungan melalui proses intuitif untuk akhirnya sampai kepada kesimpulan. Hasil belajar merupakan perubahan yang terjadi pada diri siswa, baik aspek kognitif, afektif, dan psikomotor sebagai hasil dari kegiatan belajar.Berdasarkan hasil penelitian yang dilakukan secara menyeluruh didukung dengan datakurat bahwa terdapat pengaruh model pembelajaran Discovery Learning terhadap hasil belajar siswa pada materi matriks di Kelas XI SMK Negeri 2 Situbondo Tahun Ajaran 2018/2019, hal ini sesuai hasil perhitungan uji $\mathrm{t}$, dimana $\mathrm{t}$ hitung $>\mathrm{t}$ tabel $(3,126>2,01)$ dan $\rho$ value $(0,003)<$ 0,05 pada taraf signifikansi $5 \%$. Sedangkanhasil penelitian nilai rata-rata menunjukkan bahwa hasil yang diperoleh untuk kemampuan akhir kelompok eksperimen dengan Model Pembelajaran Discovery Learning diperoleh ratarata 78,85 dan untuk kelompok kontrol dengan metode konvensional diperoleh rata-rata 74,62 disimpulkan ada perbedaan yang signifikan antara nilai rata-rata kelas eksperimen dengan nilai rata-rata kelas kontrol sebesar 42,3\%.
\end{abstract}

Kata kunci : Discovery Learning, Hasil Belajar

ABSTRACT : Discovery Learning is a learning model where learners understand their own concepts, meanings, and relationships through intuitive processes to finally come to conclusions. Learning outcomes are changes that occur in students, both cognitive, affective, and psychomotor aspects as a result of learning activities.Based on the results of research conducted thoroughly supported by accurate data and can be accountable for the truth, it 
can be concluded is there is influence of learning model of Discovery Learning on student learning outcomes on matrix material in Class XI SMK Negeri 2 Situbondo Academic Year 2018/2019, this is in accordance with the results of the $t$ test calculation, where $t$ arithmetic $>t$ table $(3.126>2.01)$ and $\rho$ value (0.003) $<0.05$ at 5\% significance level. While the results of the average value of research indicate that the results obtained for the final ability of the experimental group with Learning Discovery Learning Model obtained an average of 78.85 and for the control group with the conventional method obtained an average of 74.62 concluded there is a significant difference between the values the average of the experimental class with the average grade of control class is $42.3 \%$. So the hypothesis stating that

Keywords :Discovery Learning, Learning Outcomes

\section{PENDAHULUAN}

Pendidikan merupakan salah satu hal yang terpenting dalam kehidupan manusia, karena melalui pendidikan akan menciptakan manusia yang berpotensi, kreatif dan memiliki ide cemerlang sebagai bekal untuk memperoleh masa depan yang lebih baik (Fitriyah, 2017). Pendidikan sebagai suatu system pencerdasan anak bangsa, dewasa ini dihadapkan pada berbagai persoalan, baik ekonomi, social budaya, maupun politik. Secara kuantitatif dapat dikatakan pendidikan di Indonesia telah mengalami kemajuan (Hamzah, 2014). Pendidikan juga merupakan usaha sadar secara sengaja dirancang untuk mencapai tujuan yang telah ditetapkan. Salah satu tujuan pendidikan untuk meningkatkan kualitas sumber daya manusia. Melalui pendidikan yang baik, kita akan mudah mengikuti perkembangan zaman yang akan datang, khususnya perkembangan dalam bidang Ilmu Pengetahuan dan Teknologi (IPTEK) (Bambang, 2014).

Berhasilnya tujuan pembelajaran matematika disekolah ditentukan oleh banyak faktor diantaranya faktor guru dalam melaksanakan proses pembelajaran dikelas, karena guru secara langsung dapat mempengaruhi, membina dan meningkatkan kecerdasan serta keterampilan siswa dalam belajar (Fitriyah, 2017). 
Menurut Kowiyah (2012), Matematika merupakan salah satu mata pelajaran pokok yang diajarkan pada setiap jenjang pendidikan termasuk sekolah menengah atas, tetapi tidak sedikit peserta didik yang merasa kesulitan dalam memahami konsep-konsep dalam mata pelajaran matematika terutama dimateri Matrik. Mempelajari matematika diperlukan suatu proses berpikir kritis, karena matematika pada hakikatnya berkenaan dengan stuktur dan ide abstrak yang disusun secara sistematis dan logis (Susanto, 2013).

Model pembelajaran matematika pun memiliki peran sangat penting dalam kegiatan belajar mengajar, karena dengan model pembelajaran yang tepat akan memudahkan siswa untuk memperoleh pengetahuan yang mendalam tentang materi pelajaran matematika mengenai Matrik yang diajarkan oleh guru. Namun pada kenyataan dilapangan siswa sebagai generasi penerus belum bisa meningkatkan hasil belajar terutama pada mata pelajaran matematika, khususnya pada materi matriks di kelas XI di SMK Negeri 2 Situbondo. Penggunaan model pembelajaran matematika oleh guru belum maksimal sesuai dengan apa yang diharapkan. Masih banyak guru yang belum menggunakan model pembelajaran matematika. Seharusnya model pembelajaran matematika dapat digunakan guru dengan semaksimal mungkin untuk membantu siswa lebih mudah dalam memahami konsep-konsep dalam mata pelajaran matematika (Hadiono, 2016).

Model pembelajaran yang dapat membuat siswa lebih aktif mendapat hasil belajar yang baik, menyenangkan sehingga siswa antusias bertanya, memperhatikan penjelasan guru dan siswa mampu menemukan konsep dari apa yang disampaikan guru ketika guru menggunakan model pembelajaran yang berbeda dari biasanya yaitu model pembelajaran Discovery Learning. Penerapan Model Discovery Learning dalam kegiatan pembelajaran melibatkan langkahlangkah pembelajaran yang diikuti oleh peserta didik. Bahan ajar yang disusun dengan Model Discovery Learning akan menjadi bahan ajar berorientasi pada peserta didik dalam meningkatkan keterampilan berpikir peserta didik dan meningkatkan hasil belajar siswa di SMK Negeri 2 Situbondo dalam materi matriks (Efendi, 2016). 
Matriks merupakan susunan bilangan yang diatur menurut aturan baris dan kolom dalam suatu jajaran berbentuk persegi atau persegi panjang. Susunan bilangan itu biasanya diletakkan dalam kurung biasa ( ) atau kurung siku [ ]. Teori matriks merupakan salah satu cabang ilmu aljabar linier yang menjadi pembahasan penting dalam ilmu matematika. Sejalan dengan perkembangan ilmu pengetahuan, aplikasi matriks banyak dijumpai dalam kehidupan sehari-hari, baik dalam bidang matematika terapannya (Aksin dkk, 2017).

Hasil Belajar yang tinggi atau rendah menunjukkan keberhasilan guru dalam menyampaikan materi pelajaran dalam proses pembelajaran. Hasil belajar dapat dikatakan tuntas apabila telah memenuhi standar Kriteria Ketuntasan Minimal (KKM) yaitu 75 yang ditetapkan oleh guru mata pelajaran matematika pada materi matriks. Siswa menganggap matematika terlalu sukar (Indrawati dkk., 2015).

\section{BAHASAN UTAMA}

Pembelajaran merupakan aktualisasi kurikulum menuntut keaktifan guru dalam menciptakan kegiatan siswa sesuai dengan rencana yang telah diprogramkan. Dalam pembelajaran matematika siswa kesulitan dalam menerima materi yang diajarkan, untuk mengantisipasi hal tersebut, pembelajaran matematika dimulai dengan pengenalan masalah yang sesuai dengan situasi kehidupan sehari-hari (Simanulang, 2013)

Pembelajaran matematika merupakan suatu proses belajar mengajar yang dibangun guru dalam mengembangkan kreativitas berpikir siswa, meningkatkan kemampuan berpikir siswa, serta mengkontruksi pengetahuan baru siswa sebagai upaya meningkatkan penguasa yang baik terhadap materi matematika. Tujuan pembelajaran matematika sendiri untuk belajar yang berhubungan dengan cara informasi atau konsep pelajaran yang disajikan pada siswa melalui penerimaan dan penemuan, sedangkan tujuan berikutnya adalah untuk belajar bermakna yaitu belajar memahami apa yang sudah diperolehnya, dan dikaitkan dengan keadaan lain sehingga apa yang ia pelajari akan lebih dimengerti terutama di pelajaran matrik (Suharmanto, 2014). 
Model pembelajaran Discovery Learning merupakan model pembelajaran dimana peserta didik memahami sendiri konsep, arti, dan hubunganmelalui proses intuitif untuk akhirnya sampai kepada kesimpulan (Efendi, 2016). Menurut Fitriyah dkk. (2017), mengemukakan bahwa proses pembelajaran yang terjadi bila materi pembelajaran tidak disajikan dalam bentuk finalnya, tetapi diharapkan siswa mengorganisasi sendiri. Model Discovery Learning melibatkan arahan guru untuk mengatur aktivitas yang dilakukan peserta didik seperti mencari, mengolah, menelusuri, dan menyelidiki meskipun model pembelajaran penemuan merupakan pendekatan pengajaran dengan panduan yang minimal.

Model pembelajaran Discovery Learning ini memiliki kelebihan yaitu menumbuhkan rasa senang pada peserta didik karena tumbuhnya rasa senang pencarian yang tentunya selalu berhasil, menyebabkan peserta didik mengarahkan kegiatan belajarnya sendiri dengan melibatkan akalnya dan motivasi sendiri selama proses pembelajaran berlangsung di kelas. Model pembelajaran Discovery Learning membantu peserta didik memperkuat konsep dirinya untuk memperoleh kepercayaan bekerja sama dengan teman-temannya, peserta didik akan mengerti konsep dasar dan ide-ide secara lebih baik pada setiap pembelajaran yang diikutinya dan mendorong peserta didik selalu berfikir dan bekerja keras atas inisiatif sendiri (Eka fitri, 2018).

Adapun langkah-langkah dalam mengaplikasikan Model Discovery Learning di dalam kelas menurut Syah (dalam Wahjudi, 2015), sebagai berikut; 1) Stimulation (Stimulasi atau Pemberian Rangsangan), 2) Problem Statement (Pernyataan atau Identifikasi Masalah), 3) Data Collection (Pengumpulan Data), 4) Data Processing (Pengolahan Data), 5) Verification (Pembuktian), 6) Generalization (Menarik Kesimpulan atau Generalisasi)

Menurut Indrawan dan Yaniawati (2014), Hasil belajar merupakan hal yang dapat dipandang dari dua sisi yaitu sisi siswa dan sisi guru. Dari sisi siswa, hasil belajar merupakan tingkat perkembangan mental yang lebih baik bila dibandingkan sebelum belajar. Tingkat perkembangan mental tersebut terwujud pada jneis-jenis ranah kognitif, efektif dan psikomotor. Sedangkan dari sisi guru, hasil belajar merupakan saat terselesaikannya bahan pelajaran. 
Indikator hasil belajar yang ingin dicapai dalam penelitian ini meliputi 3 aspek yakni aspek 1)kognitif, 2)aspek afektif dan 3) aspek psikomotorik. Namun, peneliti membatasi hanya pada aspek kognitif yang meliputi pengetahuan, pemahaman, aplikasi, dan analisis, hal itu nanti akan terlihat saat berlangsungnya proses pembelajaran menggunakan model Discovery Learning siswa berusaha untuk menemukan pengetahuannya sendiri guru hanya membantu serta membimbing dan pembelajaran berpusat pada siswa dengan siswa menggali potensi yang ada dalam diri siswa (Purwanto, 2009).

Adapun hasil belajar dari penelitian sebelumnya yang berkaitan dengan Pengaruh Model Pembelajaran Discovery Learning Terhadap Hasil Belajar Siswa sebagai berikut;

1) Pengaruh Model Pembelajaran Discovery Learning Terhadap Hasil Belajar Matematika Siswa MAN Model Kota Jambi yang diteliti oleh Fitriyah, Ali Murtadlo, dan Rini Warti menyimpulkan bahwa taraf signifikan 5\% diperoleh nilai $\mathrm{t}$ tabel $=1,99$ dengan nilai $\mathrm{t}$ hitung $=2,002$ sehingga $1,99<2,002$ dengan demikian $\mathrm{H} 0$ ditolak dan $\mathrm{H}_{\mathrm{a}}$ diterima. Artinya ada pengaruh Model Pembelajaran Discovery Learning Terhadap Hasil Belajar Matematika Siswa MAN Model Kota Jambi;

2) Pengaruh Model Pembelajaran Discovery Learning Terhadap Hasil Belajar Siswa Kelas X Teknik Audio Video Pada Mata Pelajaran Teknik Elektronika Dasar Di SMK Negeri 3 Surabaya yang diteliti oleh Irene Indrawati dan Lusia Rakhmawati menyimpulkan bahwa hasil belajar siswa dengan menggunakan model pembelajaran Discovery Learning lebih baik dari hasil belajar siswa dengan menggunakan model pembelajaran langsung dengan perolehan uji-T bertaraf signifikansi $\alpha=0,05$ diperoleh nilai $t_{\text {hitung }}=2,851>t_{\text {tabel }}=1,67$. Nilai rata-rata kelas eksperimen sebesar 77,67 dan nilai rata-rata kelas kontrol sebesar 71,17;

3) Pengaruh Model Pembelajaran Discovery Learning Terhadap Hasil Belajar Siswa Pada Materi Pokok Suhu Dan Kalor yang diteliti Muhammad Kadri dan Meika Rahmawati menyimpulkan bahwa hasil penelitian menunjukkan nilai rata-rata post test kelas eksperimen 72,50 dan kelas kontrol 64,00. Hasil 
uji t satu pihak dengan taraf signifikasi 0,05 diperoleh nilai $t_{\text {hitung }}=2,88$ dan $t_{\text {tabel }}=2,002$, sehingga $t_{\text {hitung }}>t_{\text {tabel maka disimpulkan bahwa ada perbedaan akibat }}$ pengaruh Model Pembelajaran Discovery Learning terhadap hasil belajar siswa pada materi pokok suhu dan kalor;

\section{METODE PENELITIAN}

Rancangan penelitian menggunakan Eksperimen Semu (Quasi Experimental Design). Penelitian ini merupakan penelitian kuantitatif yang analisisnya pada data numerik (angka) diolah dengan metode statistika menggunakan SPSS (Statistical Product and Service Solutions) (Buchari, 2017). Desain penelitian eksperimen yang digunakan dalam penelitian berbentuk Nonequivalent Control Group Design. Dalam penelitian ini peneliti menggunakan pretest dan posttest pada kelas eksperimen maupun kelas kontrol. Populasi seluruh siswa kelas XI TAV SMK Negeri 2 Situbondo. Sedangkan Sampel yang digunakan sebanyak 2 kelas, yaitu kelas XI TAV 1 terdiri dari 26 siswa sebagai kelas eksperimen dan XI TAV 2 terdiri dari 26 siswa sebagai kelas kontrol. Teknik pengumpulan data yang digunakan dengan menggunakan observasi, pretest, postest, dan dokumentasi. Tes dilaksanakan sebelum dan setelah siswa diberi perlakuan.

Teknik analisis data dalam penelitian menggunakan uji validitas, uji reliabilitas, uji daya beda, uji kesukaran soal, dan uji-t. Data merupakan unsur mutlak dalam penelitian, yang mana data tersebut masih harus di analisis menggunakan teknik tertentu yang sesuai dengan sifat data (Sugiyono, 2014)

\section{HASIL DAN PEMBAHASAN}

1. Uji validitas, digunakan untuk mengetahui apakah data itu valid atau tidak.Untuk menentukan validitas masing-masing variabel adalah dengan melihat tabel $\mathrm{r}$ product moment $\left(\mathrm{r}_{\mathrm{xy}}\right)$, dengan berdasarkan taraf signifikansi $(\alpha)$ $5 \%$ yaitu 0.576. Jika nilai $r_{x y}<t_{\text {tabel }}$ maka dikatakan tidak valid dan jika $r_{x y}>r$ tabel maka dikatakan valid. Teknik korelasi yang digunakan adalah korelasi Product Moment.

Hasil uji validitas terhadap skor-skor variabel sebagai berikut ;

Tabel 1. Klasifikasi Uji Validitas 


\begin{tabular}{ccc}
\hline $\begin{array}{c}\text { Butir } \\
\text { Soal }\end{array}$ & Korelasi & Signifikansi \\
\hline 1 & 0,8699 & $\begin{array}{c}\text { Sangat } \\
\text { Signifikan }\end{array}$ \\
\hline 2 & 0,8699 & $\begin{array}{c}\text { Sangat } \\
\text { Signifikan }\end{array}$ \\
\hline 3 & 0,7352 & $\begin{array}{c}\text { Sangat } \\
\text { Signifikan }\end{array}$ \\
\hline 4 & 0,8699 & $\begin{array}{c}\text { Sangat } \\
\text { Signifikan }\end{array}$ \\
\hline 5 & 0,6794 & Signifikan \\
\hline 6 & 0,6628 & Signifikan \\
\hline 7 & 0,8171 & $\begin{array}{c}\text { Sangat } \\
\text { Signifikan }\end{array}$ \\
\hline 8 & 0,8699 & $\begin{array}{c}\text { Sangat } \\
\text { Signifikan }\end{array}$ \\
\hline 10 & 0,7002 & Signifikan \\
\hline
\end{tabular}

Sumber: Data diolah 2019.

Dari masing-masing butir soal yang di uji validitasnya menyatakan bahwa

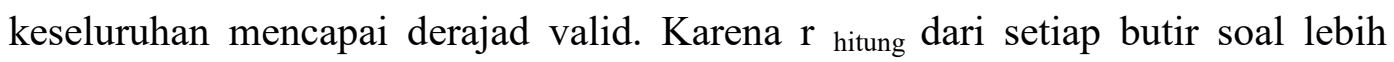
besar dari pada $r_{\text {tabel }}(0,576)$.

2. Uji reliabilitas, bertujuan mengukur tingkat kekonsistenan instrumen tes hasil belajar. Dalam pengujian reliabilitas dilakukan dengan menggunakan teknik Alpha Cronbach. Harga $\mathrm{r}$ hitung yang diperoleh dikonsultasikan harga $\mathrm{r}$ dalam tabel Product Moment dengan taraf signifikan 5\%. Soal dikatakan reliabilitas jika harga $r$ hitung $>r$ tabel. Dari perhitungan, maka diperoleh nilai reliabilitas tesnya adalah 0,91 . Karena rhitung $>$ rtabel $(0,91>0,576)$ dapat disimpulkan bahwa instrumen tersebut reliabeldan menurut keterangan kategori bahwa 0,91 masuk ke dalam kategori tinggi dan dengan kata lain instrumen ini layak untuk digunakan dalam penelitian. 
3. Uji indeks kesukaran digunakan untuk mengetahui tingkat kesukaran soal itu apakah sedang, sukar, atau mudah. Berdasarkan dari hasil pengolahan data yang peneliti peroleh melalui hitung manual maka dihasilnya data pada tabel berikut;

Tabel 2. Klasifikasi Tingkat Kesukaran

\section{Butir Soal}

\begin{tabular}{|c|c|c|}
\hline $\begin{array}{c}\text { Nomer } \\
\text { Soal }\end{array}$ & $\begin{array}{c}\text { Index } \\
\text { Kesukaran }\end{array}$ & Klasifikasi \\
\hline 1 & 4,25 & Sedang \\
\hline 2 & 4,00 & Sedang \\
\hline 3 & 4,25 & Sedang \\
\hline 4 & 4,25 & Sedang \\
\hline 5 & 4,25 & Sedang \\
\hline 6 & 4,00 & Sedang \\
\hline 7 & 4,50 & Sedang \\
\hline 8 & 4,00 & Sedang \\
\hline 9 & 4,25 & Sedang \\
\hline 10 & 4,25 & Sedang \\
\hline
\end{tabular}

Sumber: Data diolah 2019.

Hasil dari klasifikasi tingkat kesukaran di atas menunjukkan bahwa dari jumlah butir soal sebanyak 10 dengan subyek 40 siswa masuk ke klasifikasi sedang.

4. Daya beda adalah kemampuan suatu soal membedakan antara siswa yang berkemampuan tinggi dengan siswa yang berkemampuan rendah. Berdasarkan dari hasil pengolahan data maka dihasilkanpada tabel berikut; 
Tabel 3.Klasifikasi Daya Beda

Sumber: Data diolah 2019

\begin{tabular}{|c|c|c|}
\hline $\begin{array}{c}\text { Nomer } \\
\text { Soal }\end{array}$ & $\begin{array}{c}\text { Daya } \\
\text { Beda }\end{array}$ & Klasifikasi \\
\hline 1 & 5,8333 & Baik \\
\hline 2 & 6,6667 & Baik \\
\hline 3 & 5,8333 & Baik \\
\hline 4 & 5,8333 & Baik \\
\hline 5 & 5,8333 & Baik \\
\hline 6 & 6,6667 & Baik \\
\hline 7 & 5,000 & Baik \\
\hline 8 & 6,6667 & Baik \\
\hline 9 & 5,8333 & Baik \\
\hline 10 & 5,8333 & Baik \\
\hline
\end{tabular}

Data di atas menunjukkan bahwa dari jumlah butir soal sebanyak 10 daya pembeda yang semua masuk ke dalam klasifikasi baik.

5. Hasil Data Tes

Tabel 4. Distribusi Nilai PreTest Kelas

Eksperimen

\begin{tabular}{cc}
\hline Kelas Interval & Frekuensi \\
\hline $30-43$ & 1 \\
\hline $44-57$ & 6 \\
\hline $58-71$ & 6 \\
\hline $72-85$ & 5 \\
\hline $86-100$ & 8 \\
\hline Jumlah & 26
\end{tabular}

Frekuensi nilai tertinggi siswa terdapat pada rentang nilai $86-100$ yaitu sebanyak 8 siswa dan frekuensi terendah terdapat pada rentang nilai 30 - 43 yaitu sebanyak 1 siswa. Dari perolehan nilai pretest kelas eksperimen tersebut dapat diketahui kemampuan siswa dalam pelajaran matematika 
materi matriks sebelum diberi perlakuan menggunakan Model Pembelajaran Discovery Learning.

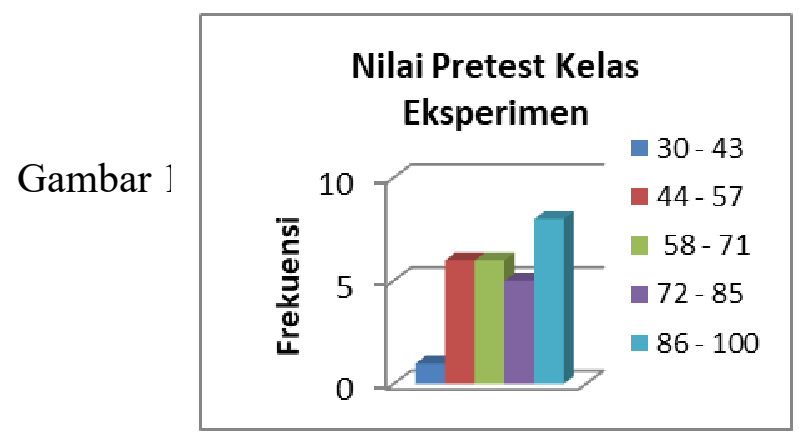

Tabel 5. Distribusi Nilai PreTest Kelas

Kontrol

\begin{tabular}{cc}
\hline Kelas Interval & Frekuensi \\
\hline $40-51$ & 2 \\
\hline $52-63$ & 5 \\
\hline $64-75$ & 6 \\
\hline $76-87$ & 7 \\
\hline $88-100$ & 6 \\
\hline Jumlah & 26
\end{tabular}

Frekuensi nilai tertinggi siswa terdapat pada rentang nilai 76 - 87yaitu sebanyak 7 siswa dan frekuensi terendah terdapat pada rentang nilai 40 51yaitu sebanyak 2 siswa. Dari perolehan nilai pretes kelas kontrol tersebut dapat diketahui kemampuan siswa dalam pelajaran matematika materi matriks sebelum diberi perlakuan menggunakan metode konvensional.

Tabel 6. Distribusi Nilai Post Test Kelas

Eksperimen

\begin{tabular}{cc}
\hline Kelas Interval & Frekuensi \\
\hline $50-59$ & 1 \\
\hline $60-69$ & 2 \\
\hline $70-79$ & 6 \\
\hline $80-89$ & 9 \\
\hline
\end{tabular}




\begin{tabular}{cc}
\hline $90-100$ & 8 \\
\hline Jumlah & 26 \\
\hline
\end{tabular}

Frekuensi nilai tertinggi siswa terdapat pada rentang nilai $80-89$ yaitu sebanyak 9 siswa dan frekuensi terendah terdapat pada rentang nilai 50 - 59 yaitu sebanyak 1 siswa. Dari perolehan nilai postes kelas eksperimentersebut dapat diketahui kemampuan siswa dalam pelajaran matematika materi matriks sesudah diberi perlakuan menggunakan Model Pembelajaran Discovery Learning.

Tabel 7.Distribusi Nilai PosTest Kelas

Kontrol

\begin{tabular}{cc}
\hline Kelas Interval & Frekuensi \\
\hline $50-59$ & 4 \\
\hline $60-69$ & 5 \\
\hline $70-79$ & 4 \\
\hline $80-89$ & 5 \\
\hline $90-100$ & 8 \\
\hline Jumlah & 26
\end{tabular}

Frekuensi nilai tertinggi siswa terdapat pada rentang nilai 90 100yaitu sebanyak 8siswa dan frekuensi terendah terdapat pada rentang nilai 50 - 59yaitu sebanyak 4 siswa. Dari perolehan nilai postest kelas kontroltersebut dapat diketahui kemampuan siswa dalam pelajaran matematika materi matriks sesudah diberi perlakuan menggunakan metode konvensional.

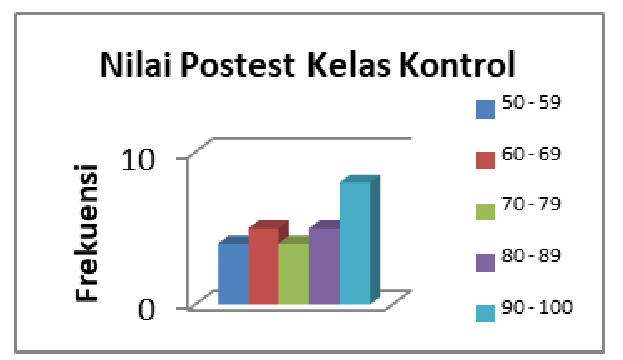

Gambar 2.Histogram Nilai postest kelas kontrol 


\section{Uji-T}

Untuk pengujian hipotesis dilakukan dengan uji-t dua pihak melalui program SPSS menggunakan Independent Sample T-Test dengan asumsi kedua varians homogen (Equal Varians Assumed) dengan taraf signifikasi 0,05. Berikut penjelasan dari pengujian hipotesis tersebut;

Hipotesis yang akan diuji dalam penelitian ini adalah $\mathrm{H}_{\mathrm{o}}$ : Tidak Ada Pengaruh Model Pembelajaran Discovery Learning Terhadap Hasil Belajar Siswa Pada Materi Matriks di Kelas XI SMK Negeri 2 Situbondo Tahun Ajaran 2017/2018;

$\mathrm{H}_{\mathrm{a}}$ : Ada Pengaruh Model Pembelajaran Discovery Learning Terhadap Hasil Belajar Siswa Pada Materi Matriks di Kelas XI SMK Negeri 2 Situbondo Tahun Ajaran 2017/2018.

Adapun kriteria pengambilan keputusan adalah sebagai berikut;

1. Jika $t_{\text {hitung }}<\mathrm{t}_{\text {tabel }}$, maka Ho diterima dan Ha ditolak

2. Jika $\mathrm{t}_{\text {hitung }}>\mathrm{t}_{\text {tabel}}$, maka Ho ditolak dan Ha diterima

Berdasarkan probabilitas;

1. Jika Sig value $<0,05$, maka Ho ditolak dan Ha diterima

2. Jika Sig value $>0,05$, maka Ho diterima dan Ha ditolak

Berdasarkan perhitungan diperoleh $\mathrm{t}$ hitung $>\mathrm{t}$ tabel $(3,126>2,01)$ dan $\rho$ value $(0,003)<0,05$, maka Ha diterima. Jadi, dapat disimpulkan bahwa ada pengaruh yang signifikan hasil belajar matematika siswa kelas eksperimen dan kelas kontrol pada tes akhir (post test) berbeda signifikan.

Hasil perhitungan rata-rata menunjukkan bahwa hasil penelitian yang diperoleh untuk kemampuan akhir kelompok eksperimen dengan Model Pembelajaran Discovery Learning diperoleh rata-rata 78,85, sedangkan untuk kelompok kontrol dengan metode konvensional diperoleh rata-rata 74,62 sehingga perbedaan tersebut sebesar 8,80 dan kalau dipresentasekan sama dengan 4,23 x 10 x $100 / 100=42,3 \%$.Disimpulkan ada perbedaan yang signifikan antara nilai ratarata kelas eksperimen dengan nilai rata-rata kelas kontrol sebesar 42,3\% dalam pembelajaran matematikaMateri Matriks di Kelas XI SMK Negeri 2 Situbondo Tahun Pelajaran 2018/2019. 


\section{PENUTUP}

Berdasarkan tujuan penelitian dan pembahasan yang telah dilakukan mengenai pengaruh Model Pembelajaran Discovery Learning Terhadap Hasil Belajar Siswa Pada Materi Matriks di Kelas XI SMK Negeri 2 Situbondo Tahun Pelajaran 2017/2018 terbukti berpengaruh. Hal ini ditunjukkan dari hasil uji hipotesis post test yang menyatakan nilai Sesuai dengan perhitungan nilai t hitung $>$ t tabel $(3,126>2,01)$ dan $\rho$ value $(0,003)<0,05$. Dari hasil perhitungan rata-rata menunjukkan bahwa hasil penelitian yang diperoleh untuk kemampuan akhir kelompok eksperimen dengan Model Pembelajaran Discovery Learning diperoleh rata-rata 78,85, sedangkan untuk kelompok kontrol dengan metode konvensional diperoleh rata-rata 74,62sehingga perbedaan tersebut sebesar 4,23 dan kalau dipresentasekan sama dengan $4,23 \times 10 \times 100 / 100=42,3 \%$,

\section{DAFTAR PUSTAKA}

Aksin. N., Miyanto, Astuti, A.Y. 2017. Matematika SMA/MA/SMK/MAK Kelas XI Semester I Kurikulum 2013. Klaten : Intan Pariwara

Arikunto. S. 2010. Prosedur Penelitian Suatu Pendekatan Praktik. Jakarta: Rineka Cipta

Bambang. 2014. Penerapan Discovery Learning untuk Meningkatkan Hasil Belajar Siswa Kelas VI B Mata Pelajaran Matematika Pokok Bahasan Keliling dan Luas Lingkaran di SDN Tanggul Wetan 02 Kecamatan Tanggul Kabupaten Jember Vol. 3. http://fkipunram,rf.gd/ifkip3. Diakses Pada Tanggal 09 Maret 2018

Eka Fitri. A. 2018. Implementation Of Discovery Learning Model To Improve Student's Mathematics Learning Achievement At Class Xi Science 2 Sma Negeri 1 Tempuling. Jurnal Jom Fkip - Ur Volume 6 Edisi 1 Januari Juni 2019

Efendi, D. 2016. Pengembangan Bahan Ajar Matematika Dengan Model Discovery Learning Untuk Mengembangkan Keterampilan Berpikir Kritis (Studi pada Siswa Kelas VIII Semester Genap SMPN 1 Seputih Agung 
Tahun Pelajaran 2015/2016). http://digilib.unila.ac.id. Diakses pada tanggal 09 Maret 2018.

Fitriyah. Murtadlo, A., Warti, R. 2017. Pengaruh Model Pembelajaran Discovery LearningTerhadap Hasil Belajar Matematika Siswa MAN Model Kota Jambi. Jurnal Pelangi Vol. 9 Nomor 2. http://ejournal.stkippgrisumbar.ac. id/index.php/pelangi/article/view/1898.Diakses pada tanggal 09 Maret 2018

Hamzah, 2014. Profesi Kependidikan Problem , Solusi, dan Reformasi Pendidikan di Indonesia. Jakarta.Penerbit:Bumi Aksara.

Hadiono. 2016. Penerapan Model pembelajaran Discovery Learning untuk meningkatkan motivasi dan hasil belajar Siswa kelas VIII-D SMPN 2 Kamal Materi Cahaya. Jurnal Pena Sains Vol 3, No 2. Fakultas Ilmu Pendidikan Universitas Trunojoyo. Madura.

Indrawan, R. dan Yaniawati, P. 2014. Metodologi Penelitian Kunatitatif, Kualitatif, dan Campuran untuk Manajemen, Pembangunan, dan Pendidikan. Bandung. Penerbit : Refika Aditama.

Johar. A. 2017. SPSS 24 Untuk Penelitian dan Skripsi.Jakarta.Penerbit: PT Elex Media Komputindo.

Kowiyah. 2012. Keterampilan Berpikir Kritis. Jurnal Pendidikan Dasar Vol. 3, No.5.http://digilib.unila.ac.id. Diakses pada tanggal 09 Maret 2018

Purwanto. 2009. Evaluasi Hasil Pembelajaran. Pustaka Pelajar. Yogyakarta.

Prasetianto. D. 2017. Pengaruh Penggunaan Model Discovery LearningTerhadap Hasil Belajar IPS Pada Pembelajaran Terpadu Kelas IV SD Negeri 1 Patoman Tahun Ajaran 2016/2017. http://digilib.unila.ac.id/27802/. Diakses pada tanggal 09 Maret 2018.

Riduwan dan Sunarto. 2017.Pengantar Statistik Untuk Penelitian Pendidikan, Sosial, Ekonomi, Komunikasi, dan Bisnis. Bnadung. Penerbit: Alfabeta.

Susanto. A. 2013.Teori Belajar dan Pembelajaran Di Sekolah Dasar.Jakarta : Penerbit Kencana.

Sugiyono. 2014. Metode Penelitian Kuantitatif Kualitatif Dan R \& D. Bnadung:Penerbit Alfabeta. 
Simanulang. J. 2013. "Pengembangan Bahan Ajar Materi Himpunan Konteks Laskas Pelangi Dengan Pendekatan Pendidikan Matematika Realistik Indonesia (PMRI) Kelas VII Sekolah Menengah Pertama”. Jurnal Pendidikan Matematika. Volume 2 No. 2 Juli 2013.

Suharmanto. 2014. "Pengembangan Media Pembelajaran Papan Hitung Pembagian Pada Mata Pelajaran Matematika Sekolah Dasar Kelas 2". Jurnal Tekhnologi Pendidikan. Desember 2016

Wahjudi. E. 2015. Penerapan Discovery LearningDalam Pembelajaran IPA Sebagai Upaya Untuk Meningkatkan Hasil Belajar Siswa Kelas IX-I di SMP Negeri 1 Kalianget.Jurnal Lentera Sains (Lensa) Vol. 5. http://www.scribd.com/mobile/document/36740 4123/5-1-2-eko-wahyudi. Diakses pada tanggal 09 Maret 2018

Widodo dan Widayanti. L. 2013. Peningkatan Aktivitas Belajar dan Hasil Belajar Siswa dengan Metode Problem Based LearningPada Siswa Kelas VIIA MTs Negeri Donomulyo Kulon Progo Tahun Pelajaran 2012/2013. Jurnal Fisika Indonesia Vol. 17 Nomor 49. http://pdm-mipa.ugm.ac.id/ ojs/index.php/jfi/article/view/831. Diakses pada tanggal 09 Maret 2018 